\title{
UTILIZATION OF SESAME PROCESSING BYPRODUCTS IN PREPARING SOME FUNCTIONAL BAKERY PRODUCTS
}

\author{
HODA H. A. HAFEZ \\ Food Technology Research Institute, Agriculture Research Center, Giza, Egypt.
}

(Manuscript received 8 May 2018)

\begin{abstract}
$\mathrm{T}$ his study aimed to utilize defatted sesame oil cake (DSC) and sieved sesame waste from tahini processing (SSWPT) to improve the nutritional value of two types of crackers, wheat crackers and corn crackers (free gluten) for celiac disease patient. The sesame processing wastes were evaluated for their safety by aflatoxin determination. Also these products were tested for water holding capacity and oil holding capacity for evaluation of their suitability to produce crackers. Chemical, physical and sensory evaluation to assess the nutritional and technological qualities of produced crackers were conducted. The results showed that sesame processing by products were safe, they had not aflatoxin, also they had good water holding capacity and oil holding capacity. The DSC and SSWPT contain high considerable amount of protein (30.3 and $29.5 \%)$, crud fiber (11.54 and12 \%), ash (10.53 and 5.67\%) and phenolic compounds (432 and $(975 \mathrm{mg}$ gallic/100g on dry matter respectively. The DSC and SSWPT showing high antioxidant activity.The results of the nutritional quality of wheat crackers and corn crackers indicated that significant increase in protein, crude fiber and minerals while the supplementation caused a decrease in total carbohydrates and caloric value comparing to the control. The acceptance rating score of crackers samples were highly accepted by panelists without significant difference with the control for two types of crackers. Wheat and corn crackers samples containing 20 $\%$ sesame sieved waste exhibited the best nutritional and technological qualities were highly ranked for overall liking of panelists. Peroxide value measurements indicated that the supplemented wheat crackers and supplemented corn crackers were lower in peroxide value compared to the control samples, so that we predicted the stability and keeping safety and quality of crackers. It could be concluded that using the sesame processing by products in wheat crackers and free gluten crackers as a valuable food addition enriched nutritional qualities of these products.
\end{abstract}

\section{INTRODUCTION}

Sesame (Sesamum indicum L., Pedaliaceae) is one of the most important oilseed crops in the world. It is not only a source of edible oil, but also widely used in baked goods and confectionery products. The sesame cake is a byproduct of the oil industry, which could be recovered and used as a value added product. However, in some sesame processing countries, this by-product is generally discarded or used in animal feeding (Ajayi and Adeshina 2014). 
Defatted sesame meal ( $40-50 \%$ protein content) is very important as a protein source for human consumption due to the presence of sulfur-containing amino acids, mainly methionine. Sesame protein isolate (SPI) is produced from dehulled, defatted sesame meal. As sesame is an important oil seed crop in various parts of the world and can be utilized in various food formulation for its beneficial effect. (Hassan 2013) Sesamum indicum seed cake is rich in protein and carbohydrate. The mineral composition of seed cake revealed that It is rich in phosphorus, potassium, magnesium and calcium which are essential minerals for growth.The result of the rat experiment showed that there was appreciable weight gain for the rats fed with the seed cake and no mortality was recorded. There were also no significant differences in the haematological parameters of rats from both groups. This is an indication that Sesamum seed cake might be safe for human consumption; it could probably also be used as raw materials for the pharmaceutical and food industries (Ajayi and Aeshina 2014).

Dried defatted sesame cake and sesame cake waste of tahina processing as food industry byproduct are safe to fortified bakery products attributed to the drying process directly after oil extraction from the whole sesame seeds and sieving the roasted dehulled sesame. Food drying is one of the factors affecting molds growth and consequently mycotoxins production by molds. This roasted defatted sesame seed cake (DSC) and sesame sieved waste (SSW) from tahini processing has high potential for use as a protein source or as an ingredient in the food industry. Sesame protein isolates normally are prepared by isoelectric precipitation. (Gandhi and Srivastava, 2007).

Functional properties of the roasted defatted sesame meal allow its use as food ingredients and in food formulation system such as meat and sauce products. The antioxidant properties of roasted defatted sesame cake considerably due to its higher content of polyphenolic compounds and antioxidant activity compared to the raw sesame seeds. So, defatted sesame cake can attract consumers and processors for value added based food products. Hassan (2013)

Antioxidants are compounds that can postpone oxidation processes or inhibit the propagation stage of free radical reactions in order to protect the body cells from oxidation. They possess abilities such as scavenging free radicals, reducing activity, chelating pro-oxidant metals, inhibiting lipid peroxidation and quenching singlet oxygen. Seed cakes are the by-product of cold-pressed oil and are usually used as animal feeds. It is of interest to study the bioactive compounds in the seed cakes which are beneficial to human health. Phenolic compounds are the dominant group of phytochemicals or secondary metabolites that are derived from the pentose phosphate, shikimate, and phenylpropanoid pathways in plants. Flavonoids are a large group of plant phenolics 
that consist of two aromatic rings that are joined by a 3-carbon bridge in the form of a heterocyclic ring (Hollman and Katan 1999)

Celiac disease is now recognized as one of the most common chronic diseases in the world. Celiac disease is a genetically-determined chronic inflammatory intestinal disease induced by gluten in wheat, barley, rye etc. As gluten-free products available in the market are known to have low nutritional quality as well as are more expensive than gluten-containing food products. There is a strong need to develop gluten-free products that are nutritionally complete as well as economical. (Prakritiz et al., 2016)

Gluten-free foods are safe to consume. (Prakritiz et al., 2016)

The sesame wastes are going to find widespread application as an ingredient in the food industry and bakery products. So, the aim of this study is to formulate novel wheat crackers and free gluten crackers by using roasted defatted sesame seed cake and sesame sieved waste from tahini processing, In addition to, the sesame sieved waste from tahini processing which had almost $20 \%$ fat can be particularly used as a particularly alternative source of fat in crackers preparing according to the panelists. In order to improve the nutritional value of crackers and show new dimensions of its health benefits.

\section{MATERIALS AND METHODS}

\section{Materials}

-Wheat flour 72 \% was obtained from South Giza Flour Mills Company, Egypt.

- Corn flour was obtained from Egyptian Company for Maize products $10^{\text {th }}$ Ramadan City, Cairo, Egypt.

-Defatted sesame seed cake (sesamum indicum, L.) was obtained from the local sesame oil processing factory in Cairo, Egypt.

-Sesame seed coats, the waste products produced during the manufacture of the sesame tahini were gift supplied by Elrashidi Elmizan factory, Saida Zainab, Cairo, Egypt. - Butylated hydroxyl anisole (BHA) was obtained from Egyptian Scientific Company, ElDokki, Giza, Egypt.

- sugar, corn oil, salt, cumin, pectin and baking powder were obtained from local market, Giza, Egypt.

\section{Methods}

-Preparation of defatted sesame cake (DSC): The cake obtained after the oil extraction was dried at $40{ }^{\circ} \mathrm{C}$ for $24 \mathrm{hr}$. then ground to powder and sieved to pass through a 20 mesh sieve (standard screen) then packed and kept at $4 \cdot \mathrm{C}$ until using Elleuch et al., (2012) 
- preparation of sesame sieved waste from tahini processing (SSWPT) The seed coats ( $13 \%$ of sesame seed) were dried for $24 \mathrm{~h}$ at $40{ }^{\circ} \mathrm{C}$, milled and sieved to pass through a 20 mesh sieve then packed and kept at $4 \dot{C}$ until using Elleuch et al., (2012)

-Determination of aflatoxins: Defatted sesame oil cake (DSC) and sesame sieved waste from tahini processing (SSWPT) were determined for aflatoxins according to A.O.A.C (2005)

Determination of some functional properties : Water holding capacity (WHC) and Oil holding capacity $(\mathrm{OHC})$ WHC and OHC of DSCand SSWPT were determined by the method of Gandhi and Srivastava (2007). One gram of the sample was mixed with 10 $\mathrm{ml}$ distilled water or soybean oil in centrifuge tubes and then allowed to stand for 30 $\mathrm{min}$. Samples were centrifuged at 2,822rpm for $30 \mathrm{~min}$. The supernatant was discarded and the tube was weighed. WHC and $\mathrm{OHC}$ (grams of water or oil per gram of sample) Total Polyphenols: Total phenols content of wheat crackers and corn flour crackers were determined by the method described by Gao et al., (2000) by using $0.2 \mathrm{ml}$ of Folin-Ciocalteu reagent and $2 \mathrm{ml}$ of $\mathrm{H} 2 \mathrm{O}$ and incubated at room temperature for $3 \mathrm{~min}$. then addition of $1 \mathrm{ml}$ of $20 \%$ sodium carbonate to the mixture and incubated for $1 \mathrm{hr}$ at room temperature. The absorbance of the resulting blue color was measured at $765 \mathrm{~nm}$ by spectrophotometer quantification was done with respect to the standard curve of gallic acid. The results were expressed as gallic acid equivalents (GAE) milligrammes per $100 \mathrm{gm}$ of dry weight basis.

Antioxidant Activity Determination : Quenching of 2, 2-diphenyl-1-picrylhdrazyl (DPPH) radical by DSC and SSWPT methanol extracts. The effect of extracts on the DPPH radical was estimated according to the method reported by Siddhuraju et al. (2000). A volume of $2 \mathrm{ml}$ of methanolic solution of DPPH was mixed with DSC and SSWPT methanol extracts. The mixtures were shaken and allowed to stand at room temperature for $30 \mathrm{~min}$; the absorbance of the resulting solutions was measured spectrophotometrically at $515 \mathrm{~nm}$. The percentage of DPPH radical-scavenging ability was calculated from the absorbance value at the end of $30 \mathrm{~min}$ as follows:

$\%$ scavenging $=(A 0-A 30) / A_{0} * 100$

Where $\mathrm{A} 0=$ absorbance at $0 \mathrm{~min} ; \mathrm{A} 30=\mathrm{absorbance}$ at $30 \mathrm{~min}$. 


\section{Preparation of products:}

\section{1-crackers:}

The crackers were prepared according to the method described by Wade (1988) with some modifications; the formula is shown in Table (1)

Table 1. The formula of crackers

\begin{tabular}{|l|l|l|l|l|l|l|l|l|l|l|}
\hline \multicolumn{1}{|c|}{ Sample } & $\begin{array}{c}\text { Control } \\
\text { wheat } \\
\text { cracker }\end{array}$ & \multicolumn{1}{|c|}{1} & 2 & 3 & 4 & $\begin{array}{c}\text { Control } \\
\text { corn } \\
\text { cracker }\end{array}$ & 5 & 6 & 7 & 8 \\
\hline Wheat flour 72\% & 100 & 85 & 80 & 85 & 80 & - & - & - & - & - \\
\hline Corn flour (g) & - & - & - & & & 100 & 85 & 80 & 85 & 80 \\
\hline $\begin{array}{l}\text { Defatted sesame } \\
\text { cake (g) }\end{array}$ & - & 15 & 20 & & & - & 15 & 20 & - & - \\
\hline $\begin{array}{l}\text { Sesame sieved waste } \\
\text { tahini (SSWPT) }\end{array}$ & - & - & - & 15 & 20 & - & - & & 15 & 20 \\
\hline Corn oil & 10 & 10 & 10 & - & - & 10 & 10 & 10 & - & - \\
\hline Corn oil +SSWPT & - & - & - & 10 & 10 & - & - & & 10 & 10 \\
\hline Cumin & - & 2 & 2 & 2 & 2 & - & 2 & 2 & 2 & 2 \\
\hline
\end{tabular}

Note: to every prepared sample $2 \mathrm{~g}$ baking powder, $1 \mathrm{~g}$ sugar, $2 \mathrm{~g}$ salt, $1 \mathrm{~g}$ improver (pectin) and water as dough required were added.

-Pretest experiment was carried out to determine the best mixes ratio of suggested material for this study.

-corn oil was particularly substituted in the crackers formula which contains SSWPT according to panelists to produce the best mixture ratio of corn oil and SSWPT

\section{Processing of crackers}

For making crackers the following procedure was followed -all dry ingredients were mixed with water using a laboratory mixture for $4 \mathrm{~min}$. and the resulted dough was let to rest for $15 \mathrm{~min}$. then the dough was removed from the bowel and shaped to the final form. The crackers were baked at 200C for 6 min. after baking crackers were cooled at room temperature before evaluation.

\section{Chemical analysis:}

-The chemical composition of raw materials and crackers were determined according to AOAC 2005 standard methods.

- Available carbohydrate content was estimated by difference as mentioned by Fraser and Holmes (1959)

Available carbohydrate $\%$ (on dry basic) $=100-($ protein $\%+$ fat $\%+$ ash $\%+$ fiber)

- Total calories of crackers were determined according the following equation : total calories $(\mathrm{kcal} / 100 \mathrm{~g})=4($ protein \%+ carbohydrate \%)+ 9 (fat \%) FAO/WHO (1991).

Minerals content of raw materials and products: Minerals contents i.e. $\mathrm{Fe}, \mathrm{Ca}$ and $\mathrm{Zn}$ were determined in the diluted solution of ash samples by using the atomic absorption spectrophotometer (3300 Perkin -Elmer) as described in AOAC (2005). 
Determination of peroxide value: Peroxide value (PV) Peroxide value was determined for crackers samples using AOAC (2005). Butyl Hydroxy Anisole (BHA) was used as standard

Sensory evaluation of crackers: Crackers were evaluated for their sensory characteristics by ten panelists from the staff of Bread and Pastry Research Dep., Food Technology Research Institute, Agric. Res. Center, Giza. The scoring scheme was established as mentioned by Bates et al., (1991) as follow: general appearance (20), color (20), taste (20), crispy (20), odor (20) and overall score 100 degrees.

Physical properties of crackers: Physical properties were determined according to the method described in AACC (2002). Height, weight (w), volume(v) and specific volume $\mathrm{v} / \mathrm{w}\left(\mathrm{cm}^{3} / \mathrm{gm}\right)$ for produced crackers

Statistical analysis: The obtained results for sensory evaluation were statistically analyzed by the least significant difference value (L. S. D.) at 0.05 levels probability by Snedecor and Cochran (1980).

\section{RESULTS AND DISCUSSION}

Determination of aflatoxins in raw materials: The results showed that DSC and SSWPT had not any aflatoxins compounds B1,B2, G1 and G2 as shown in Table (2), these results demonstrate that dried DSC and SSWPT are safe for fortification bakery products, attributed to drying process after oil extraction from whole sesame seeds. Food drying is one of the factors affecting molds growth and consequently mycotoxins production by molds. Gandhi and Srivastava (2007).

Table 2. aflatoxins content of raw materials

\begin{tabular}{|l|l|l|l|l|}
\hline Sample & B1 & B2 & G1 & G2 \\
\hline DSC & 0 & 0 & 0 & 0 \\
\hline SSWPT & 0 & 0 & 0 & 0 \\
\hline
\end{tabular}

Water holding capacity (WHC) and oil holding capacity of defatted sesame cake and sesame sieved waste processing tahini

Functional properties have been defined as "those physical and chemical properties that influence the behavior of proteins in food system during processing storage, cooking, and consumption" Functional properties of protein are important in food processing, and food formulation Gandhi and Srivastava (2007).

The water holding capacity of DSC and SSWPT (2.2 and $3.5 \mathrm{~g}$ water/g respectively were close to those reported by Grigelmo-Miguel, and Martin-Belleso (1999) who reported that water holding capacity and oil holding capacity were 3.1-5 g water/g sesame seed coat. Also they reported that, wheat bran, oat bran, citrus husk, and pineapple peel (2-4 g water $/ \mathrm{g}$ sample) indicates that sesame seed coats can be used as a functional ingredient to reduce calories, avoid syneresis, and modify the viscosity and texture of formulated foods. 
Oil Holding Capacity : DSC and SSWPT showed a higher oil holding capacity (1.8 and $2 \mathrm{~g}$ oil/g respectively )than other sources of fibre, e.g., orange and peach fibre, as reported by. Grigelmo-Miguel, and Martin-Belleso (1999) between 0.863 and $1.11 \mathrm{~g}$ oil/g sample). Sesame processing wastes can be used in food formulations to stabilize food with high oil content.

The results show that the greater water absorption capacity and oil absorption capacity indicated the suitability of sesame processing wastes for the preparation of bakery products. These results will throw light on further value addition towards the preparation of high protein food supplement using defatted sesame flour and soy flour. Gandhi and Srivastava (2007).

Table 3. Water holding capacity ( $\mathrm{g}$ water/g sample) and fat absorption capacity ( $\mathrm{g}$ oil/ g protein):

\begin{tabular}{|l|l|l|}
\hline Sample & WHC (g water/g sample & OHC (g oil/g sample) \\
\hline Defatted sesame cake & $2.20 \pm 1.0^{\mathrm{a}}$ & $1.8 \pm 1.0^{\mathrm{a}}$ \\
\hline Sesame sieved waste & $3.50 \pm 1.0^{\mathrm{a}}$ & $2.0 \pm 0.20^{\mathrm{a}}$ \\
\hline LSD 5\% & 1.59 & 1.99 \\
\hline
\end{tabular}

Values are means of three replicates \pm SD

The mean values with different letter or letters within the same column indicates significant differences $(p \leq 0.05)$

Total phenolic content and antioxidant activity in DSC and SSWPT:

Antioxidants play an important role to inhibit the dangerous effects of the free radicals, In general antioxidants are the compounds which lead to inhibit or delay of the oxidation of other molecules such as the inhibition of the initiation or propagation of oxidizing chain reaction ( Hollman and Katan 1999 ). Total phenolic content of DSC and SSWPT was determined by using Folin-Ciocalteu reagent method and the results is expressed as gallic acid equivalents as shown in Table (4).

It could be noticed that DSC and SSWPT were high in polyphenol content (432 and 975) $\mathrm{mg} / 100 \mathrm{~g}$ respectively, Sesame seed coats were high in antioxidant (poly phenol content). These results are nearly that found by Elleuch et al., (2012) who found that the sesame seed coat contains about $9.45 \mathrm{mg} / \mathrm{g}$ dry matter.

Concerning the result of antioxidant activity, it could be clearly observed that SSWPT had the highest level of antioxidant activity $87 \%$ comparing with DSC (40\%) SSWPT was high in total phenolic content which may be attributed to strong abilities for hydrogen-donation and scavenging of hydroxyl radicals. These results agreed with Suja et al., (2004). This can be attributed to the difference in polyphenol content and to the nature of extracted compounds. Results show that sesame testae extracts possess the ability to act as hydrogen donors and they are the primary antioxidants that react with free radicals. The scavenging effect of the absolute ethanol extraction. 
Table 4. Total poly phenol and antioxidant activity of DSC and SSWPT:

\begin{tabular}{|l|l|l|}
\hline Sample & Total phenolic $(\mathrm{mg} / 100 \mathrm{~g})$ & $\begin{array}{l}\text { Antioxidant } \\
\text { activity } \%\end{array}$ \\
\hline DSC & $432 \pm 1.0^{\mathrm{b}}$ & $40 \pm 1.5^{\mathrm{b}}$ \\
\hline SSWPT & $975 \pm 1.0^{\mathrm{a}}$ & $87 \pm 1.2^{\mathrm{a}}$ \\
\hline LSD 5\% & 1.77 & 2.17 \\
\hline
\end{tabular}

Values are means of three replicates \pm SD

The mean values with different letter or letters within the same column indicates significant differences $(p \leq 0.05)$.

Chemical Analysis of raw materials: The result of the composition of raw materials in Table (5) showed significant variation between the raw materials. DSC and SSWPT had considerable amount of protein and ash. Meanwhile corn flour had the least amount of protein. DSC and SSWPT exhibited the highest amount of fiber. SSWPT showed the highest in fat content (20.4\%) then DSC (6.06 \%). While corn flour and wheat flour contained 2.2 and $1.15 \%$ fat respectively. Corn flour showed the highest component of carbohydrate. Similar results considering composition of the above raw materials were obtained by AbdEl-Monem (2006)

Table 5. Chemical composition of raw materials (on dry weight basis).

\begin{tabular}{|l|c|c|c|c|c|c|}
\hline \multicolumn{1}{|c|}{ Sample } & $\begin{array}{c}\text { Protein } \\
\%\end{array}$ & $\begin{array}{c}\text { Ether } \\
\text { Extract } \\
\%\end{array}$ & $\begin{array}{c}\text { Ash } \\
\%\end{array}$ & $\begin{array}{c}\text { Crude } \\
\text { Fiber } \%\end{array}$ & $\begin{array}{c}\text { Available } \\
\text { Carbohydrate } \\
\%\end{array}$ & $\begin{array}{c}\text { Calories } \\
\text { Kcal/100g }\end{array}$ \\
\hline Wheat flour72\% & $11.0 \pm 0.5^{\mathrm{c}}$ & $1.15 \pm 0.2^{\mathrm{d}}$ & $0.46 \pm 0.2^{\mathrm{d}}$ & $0.51 \pm 0.04^{\mathrm{d}}$ & $86.88 \pm 1.0^{\mathrm{a}}$ & $401.87 \pm 0.1 \mathrm{a}$ \\
\hline Corn flour & $8.5 \pm 0.2^{\mathrm{d}}$ & $2.2 \pm 0.1^{\mathrm{c}}$ & $1.4 \pm 0.1^{\mathrm{c}}$ & $1.50 \pm 0.3^{\mathrm{c}}$ & $86.4 \pm 0.2^{\mathrm{a}}$ & $399.4 \pm 0.2^{\mathrm{b}}$ \\
\hline (DSC) & $30.3 \pm 0.3^{\mathrm{a}}$ & $6.06 \pm 0.03^{\mathrm{b}}$ & $10.53 \pm 0.5^{\mathrm{a}}$ & $11.54 \pm 0.2^{\mathrm{b}}$ & $41.57 \pm 0.5^{\mathrm{b}}$ & $342.02 \pm 0.5^{\mathrm{c}}$ \\
\hline (SSWPT) & $29.5 \pm 0.5^{\mathrm{b}}$ & $20.4 \pm 0.2^{\mathrm{a}}$ & $5.67 \pm 0.5^{\mathrm{b}}$ & $12.00 \pm 0.2^{\mathrm{a}}$ & $32.43 \pm 0.2^{\mathrm{c}}$ & $331.32 \pm 0.5^{\mathrm{d}}$ \\
\hline LSD 5\% & 0.64 & 0.24 & 0.59 & 0.33 & 0.92 & 0.47 \\
\hline
\end{tabular}

Values are means of three replicates \pm SD

The mean values with different letter or letters within the same column indicates significant differences $(p \leq 0.05)$.

Nutritional quality of wheat flour crackers: Table (6) exhibits the nutritional values of the crackers on dry weight basis. Data proved that the protein, ash and fiber content were increased with increasing the supplementation percentage of all samples compared to control. The significant increase in protein was pronounced more in sample 2 which contained sesame defatted cake. Crude fiber significantly increased in all supplemented samples compared to control. The maximal increase in crude fiber was pronounced more in sample 4 followed by sample 3 which contain SSWPT (the highest fiber material). Fat content ranged between $10.6 \%$ to $11.61 \%$ in all samples. These results agreed with those obtained by AbdEI-Monem (2006) who found that the sesame 
processing waste caused increasing in protein, fat, ash and fiber content in the bakery products.

Considering, total carbohydrate and calories decreased in supplemented crackers compared to control sample.

Table 6. Nutritional quality of wheat crackers (on dry weight basis).

\begin{tabular}{|l|l|l|l|l|l|l|}
\hline Sample & $\begin{array}{l}\text { Protein } \\
\%\end{array}$ & $\begin{array}{l}\text { Ether } \\
\text { extract\% }\end{array}$ & Ash \% & Fiber \% & $\begin{array}{l}\text { Available } \\
\text { Carbohydrate } \\
\%\end{array}$ & $\begin{array}{l}\text { Calories } \\
\text { Kcal } / 100 \mathrm{~g}\end{array}$ \\
\hline $\begin{array}{l}\text { Control } \\
\text { wheat } \\
\text { crackers }\end{array}$ & $10.53 \pm 1.0^{\mathrm{c}}$ & $10.60 \pm 0.5^{\mathrm{b}}$ & $4.61 \pm 0.2^{\mathrm{d}}$ & $1.80 \pm 0.02^{\mathrm{d}}$ & $72.46 \pm 1.0^{\mathrm{a}}$ & $427.36 \pm 0.3^{\mathrm{a}}$ \\
\hline 1 & $13.61 \pm 0.2^{\mathrm{b}}$ & $11.00 \pm 0.3^{\mathrm{b}}$ & $5.41 \pm 0.1^{\mathrm{b}}$ & $2.50 \pm 0.03^{\mathrm{bc}}$ & $67.4 \pm 0.01^{\mathrm{b}}$ & $423.36 \pm 1.0^{\mathrm{c}}$ \\
\hline 2 & $14.90 \pm 02^{\mathrm{a}}$ & $11.20 \pm 0.2^{\mathrm{a}}$ & $5.0 \pm 0.2^{\mathrm{bc}}$ & $2.76 \pm 0.02^{\mathrm{b}}$ & $66.14 \pm 0.1^{\mathrm{c}}$ & $424.96 \mathrm{~b} \pm 0.02^{\mathrm{b}}$ \\
\hline 3 & $12.90 \pm 0.5^{\mathrm{b}}$ & $11.50 \pm 0.5^{\mathrm{a}}$ & $5.22 \pm 0.2^{\mathrm{b}}$ & $3.00 \pm 0.03^{\mathrm{b}}$ & $67.38 \pm 0.2^{\mathrm{b}}$ & $424.62 \pm 0.2^{\mathrm{b}}$ \\
\hline 4 & $13.50 \pm 0.2^{\mathrm{b}}$ & $11.61 \pm 0.2^{\mathrm{a}}$ & $6.62 \pm 0.2^{\mathrm{a}}$ & $3.59 \pm 0.02^{\mathrm{a}}$ & $64.68 \pm 0.6^{\mathrm{d}}$ & $417.21 \pm 0.2^{\mathrm{d}}$ \\
\hline LSD 5\% & 0.84 & 0.59 & 0.30 & 0.39 & 0.85 & 0.77 \\
\hline
\end{tabular}

Values are means of three replicates \pm SD

The mean values with different letter or letters within the same column indicates significant differences $(p \leq 0.05)$

Mineral content of wheat flour crackers: Table (7). Represents the $\mathrm{Ca}, \mathrm{Fe}, \mathrm{Zn}, \mathrm{Ca}$ and $\mathrm{Mg}$ content $\mathrm{mg} / 100 \mathrm{~g}$ crackers. $\mathrm{Ca}$, Fe and $\mathrm{Zn}$ are important for growth. Iron serves as a carrier of oxygen to the tissues and as an integrated part of important enzyme in various tissues. Also, Zinc is essential for normal growth development of the immune response and participating as a cofactor for more than 300 enzymes. Data revealed that crackers samples which supplemented with DSC and SSWPT at different levels were rich in the previous investigated elements compared with the control. Ca ranged from ( 77.11 to $91.3 \mathrm{mg} / 100 \mathrm{~g}$ ) in supplemented samples and $29.1 \mathrm{mg} / 100 \mathrm{~g}$ in the control. Fe ranged from 6.11 to $8.3 \mathrm{mg} / 100 \mathrm{gm}$ in supplemented samples while it was 1.8 $\mathrm{mg} / 100 \mathrm{~g}$ in the control. $\mathrm{Zn} \mathrm{mg} / 100 \mathrm{~g}$ ranged from (1.95 to 2.35 ) in samples. While $\mathrm{Zn}$ was 0.69 in the control. This increment in minerals in samples was resulting to the crackers formulas; sesame processing wastes which rich in these minerals. However, the control was the lowest level in mineral content. These results are confirmed with those obtained by (Ajayi and Adeshina 2014).

Table 7. Mineral content of wheat crackers $(\mathrm{mg} / 100 \mathrm{~g})$.

\begin{tabular}{|l|l|l|l|}
\hline Sample & $\mathrm{Fe}$ & $\mathrm{Zn}$ & $\mathrm{Ca}$ \\
\hline Control wheat crackers & $1.80 \pm 0.2^{\mathrm{c}}$ & $0.69 \pm 0.1^{\mathrm{d}}$ & $29.1 \pm 0.4^{\mathrm{e}}$ \\
\hline 1 & $6.30 \pm 0.2^{\mathrm{b}}$ & $1.95 \pm 0.01^{\mathrm{c}}$ & $78.20 \pm 0.2^{\mathrm{c}}$ \\
\hline 2 & $8.30 \pm 0.2^{\mathrm{a}}$ & $2.35 \pm 0.1^{\mathrm{a}}$ & $91.30 \pm 0.28^{\mathrm{a}}$ \\
\hline 3 & $6.11 \pm 0.11^{\mathrm{b}}$ & $1.90 \pm 0.1^{\mathrm{c}}$ & $77.11 \pm 0.11^{\mathrm{d}}$ \\
\hline 4 & $8.11 \pm 0.11^{\mathrm{a}}$ & $2.15 \pm 0.1^{\mathrm{b}}$ & $88.33 \pm 0.17^{\mathrm{b}}$ \\
\hline LSD 5\% & 1.66 & 0.14 & 0.39 \\
\hline
\end{tabular}

Values are means of three replicates \pm SD

The mean values with different letter or letters within the same column indicates significant differences $(p \leq 0.05)$ 
Nutritional quality of free gluten crackers (on dry weight basis) : From the results in Table (8) significant fluctuation in protein and could be pronounced in sample 6 and 8. It could be noticed that ash, fat and fiber increased in supplemented crackers comparing with control. While significant decrease in carbohydrate in crackers samples Table 8. nutritional quality of free gluten crackers (on dry weight basis)

\begin{tabular}{|l|l|l|l|l|l|l|}
\hline Sample & Protein (\%) & $\begin{array}{l}\text { Ether } \\
\text { extract\% }\end{array}$ & Ash \% & $\begin{array}{l}\text { Crude } \\
\text { fiber\% }\end{array}$ & $\begin{array}{l}\text { Available } \\
\text { Carbohydrates } \\
\%\end{array}$ & $\begin{array}{l}\text { Calorie } \\
\text { Kcal/100g }\end{array}$ \\
\hline $\begin{array}{l}\text { Control } \\
\text { corn } \\
\text { crackers }\end{array}$ & $7.50 \pm 0.1^{\mathrm{c}}$ & $11.70 \pm 0.1^{\mathrm{d}}$ & $5.81 \pm 0.1^{\mathrm{d}}$ & $3.50 \pm 0.1^{\mathrm{c}}$ & $71.49 \pm 0.1^{\mathrm{a}}$ & $421.26^{\mathrm{a}}$ \\
\hline 5 & $10.30 \pm 0.1^{\mathrm{b}}$ & $12.30 \pm 0.1^{\mathrm{c}}$ & $6.60 \pm 0.1^{\mathrm{b}}$ & $4.00 \pm 0.5^{\mathrm{b}}$ & $66.80 \pm 0.2^{\mathrm{b}}$ & $419.10^{\mathrm{c}}$ \\
\hline 6 & $11.50 \pm 0.1^{\mathrm{a}}$ & $12.50 \pm 0.2^{\mathrm{c}}$ & $6.20^{\mathrm{b}} \pm 0.1^{\mathrm{c}}$ & $4.31 \pm 0.25^{\mathrm{b}}$ & $65.49 \pm 0.1^{\mathrm{c}}$ & $420.46^{\mathrm{b}}$ \\
\hline 7 & $10.50 \pm 0.1^{\mathrm{b}}$ & $13.10 \pm 0.2^{\mathrm{b}}$ & $6.51^{\mathrm{b}} \pm 0.1^{\mathrm{b}}$ & $5.12 \pm 0.1^{\mathrm{a}}$ & $64.77 \pm 0.1^{\mathrm{d}}$ & $418.98^{\mathrm{c}}$ \\
\hline 8 & $11.60 \pm 0.35^{\mathrm{a}}$ & $13.60 \pm 0.1^{\mathrm{a}}$ & $7.61^{\mathrm{a}} \pm 0.1^{\mathrm{a}}$ & $4.90 \pm 0.1^{\mathrm{a}}$ & $62.29 \pm 0.1^{\mathrm{e}}$ & $417.98^{\mathrm{d}}$ \\
\hline LSD 5\% & 0.29 & 0.24 & 0.16 & 0.42 & 0.20 & 0.20 \\
\hline
\end{tabular}

Values are means of three replicates \pm SD

The mean values with different letter or letters within the same column indicates significant differences $(p \leq 0.05)$

Mineral content of free gluten crackers: Table (9) represents the $\mathrm{Fe}, \mathrm{Ca}$ and $\mathrm{Zn}$ content $(\mathrm{mg} / 100 \mathrm{mg})$ crackers. Significant increase in the previous minerals in samples compared with the control. Our present findings are in the same findings with (Hassan 2013) who reviewed the nutritional quality of sesame processing wastes.

Table 9. mineral content of free gluten crackers $\mathrm{mg} / 100 \mathrm{~g}$ )

\begin{tabular}{|l|l|l|l|}
\hline Sample & $\mathrm{Fe}$ & $\mathrm{Zn}$ & $\mathrm{Ca}$ \\
\hline Control corn crackers & $3.50 \pm 0.1^{\mathrm{c}}$ & $2.60 \pm 0.2^{\mathrm{c}}$ & $29.50 \pm 0.5^{\mathrm{d}}$ \\
\hline 5 & $8.26 \pm 0.5^{\mathrm{b}}$ & $4.10 \pm 0.5^{\mathrm{b}}$ & $78.30 \pm 1.0^{\mathrm{c}}$ \\
\hline 6 & $10.10 \pm 0.5^{\mathrm{a}}$ & $5.30 \pm 0.3^{\mathrm{a}}$ & $91.00 \pm 0.5^{\mathrm{a}}$ \\
\hline 7 & $8.07 \pm 0.61^{\mathrm{b}}$ & $4.93 \pm 0.2^{\mathrm{a}}$ & $78.11 \pm 0.4^{\mathrm{c}}$ \\
\hline 8 & $10.13 \pm 0.1^{\mathrm{a}}$ & $5.12 \pm 0.4^{\mathrm{a}}$ & $89.10 \pm 0.39^{\mathrm{b}}$ \\
\hline LSD 5\% & 0.68 & 0.55 & 0.94 \\
\hline
\end{tabular}

Values are means of three replicates \pm SD

The mean values with different letter or letters within the same column indicates significant differences $(p \leq 0.05)$

Sensory evaluation of crackers: Sensory evaluation is considered to be a valuable tool in solving problems involving food acceptability, product improvement quality maintenance and in a new product development.

From the results presented in Table (10) it could be noticed that sensory characteristics of supplemented crackers were decreased with increasing the percentage of DSC and SSWPT in all samples except taste which improved with supplementation. Also, it could be noticed that crackers produced with DSC and SSWPT until $20 \%$ still have good acceptability. So, these levels of supplementation were selected with the control for crackers production AbdEl-Monem (2006). 
Table 10. Sensory evaluation of crackers:

\begin{tabular}{|l|l|l|l|l|l|l|l|}
\hline sample & \multicolumn{1}{|c|}{$\begin{array}{c}\text { Color } \\
(20)\end{array}$} & $\begin{array}{c}\text { Taste } \\
(20)\end{array}$ & $\begin{array}{c}\text { crispy } \\
(20)\end{array}$ & $\begin{array}{c}\text { Appearance } \\
(20)\end{array}$ & $\begin{array}{c}\text { Odor } \\
(20)\end{array}$ & $\begin{array}{c}\text { Overall } \\
\text { Score } \\
(100)\end{array}$ & Acceptance \\
\hline $\begin{array}{l}\text { Control } \\
\text { wheat } \\
\text { cracker } \\
\mathrm{s}\end{array}$ & $19.0 \pm 0.5^{\mathrm{a}}$ & $18.50 \pm 0.5^{\mathrm{a}}$ & $19.16 \pm 0.74^{\mathrm{a}}$ & $19.16 \pm 0.5^{\mathrm{a}}$ & $18.66 \pm 0.1^{\mathrm{a}}$ & $94.48 \pm 1.0^{\mathrm{a}}$ & V.G \\
\hline 1 & $17.93 \pm 1.0^{\mathrm{a}}$ & $19.50 \pm 0.5^{\mathrm{a}}$ & $18.33 \pm 1.0^{\mathrm{a}}$ & $18.0 \pm 0.5^{\mathrm{b}}$ & $19.26 \pm 0.5^{\mathrm{a}}$ & $93.02 \pm 0.4^{\mathrm{b}}$ & V.G \\
\hline 2 & $16.83 \pm 1.0^{\mathrm{ab}}$ & $19 . \pm 0.5^{\mathrm{a}}$ & $16.83 \pm 1.0^{\mathrm{b}}$ & $16.83 \pm 0.2^{\mathrm{bc}}$ & $19.26 \pm 0.5^{\mathrm{a}}$ & $89.25 \pm 0.2^{\mathrm{d}}$ & G \\
\hline 3 & $18.16 \pm 1.0^{\mathrm{a}}$ & $18.50 \pm 0.5^{\mathrm{a}}$ & $18.50 \pm 0.5^{\mathrm{a}}$ & $17.73 \pm 0.1^{\mathrm{b}}$ & $19.16 \pm 0.4^{\mathrm{a}}$ & $92.05 \pm 0.5^{\mathrm{b}}$ & V.G \\
\hline 4 & $18.50 \pm 0.2^{\mathrm{a}}$ & $18.20 \pm 1.0^{\mathrm{ab}}$ & $19.16 \pm 0.45^{\mathrm{a}}$ & $16.50 \pm 0.5^{\mathrm{bc}}$ & $19.00 \pm 0.5^{\mathrm{a}}$ & $91.36 \pm 1.0^{\mathrm{bc}}$ & V.G \\
\hline LSD 5\% & 1.34 & 1.01 & 1.24 & 0.96 & 0.99 & 1.12 & - \\
\hline
\end{tabular}

Values are means of ten replicates \pm SD

The mean values with different letter or letters within the same column indicates significant differences $(p \leq 0.05) .90-100$ very $\operatorname{good}(V G), 80-90 \operatorname{Good}(G), 70-79$ Satisfactory(S), Less than 70 Questionable (Q).

Sensory evaluation of free gluten crackers: Sensory quality attributes of the crackers expressed by experienced panelists are presented in Table11. Significant decrease was found in appearance and color with increasing the level of DSC and SSWPT. The overall score of all samples were not significant with control (except for sample no. 6) indicating that SSWPT and DSC at $15 \%$ was good quality attribute. Although the sensory characteristics scores of samples 5 and 6 had the lowest scores among all the crackers evaluated, they were showing high acceptability. So we found that DSC and SSWPT can be utilized until $20 \%$ in crackers to improve the nutritional quality with good acceptability AbdEI-Monem (2006) .

Table 11. sensory evaluation of free gluten crackers:

\begin{tabular}{|l|l|l|l|l|l|l|l|}
\hline sample & Color (20) & Taste (20) & Crispy (20) & Appearance (20) & Odor (20) & $\begin{array}{l}\text { Overall } \\
\text { Score (100) }\end{array}$ & acceptability \\
\hline $\begin{array}{l}\text { Control } \\
\text { corn } \\
\text { crackers }\end{array}$ & $19.16 \pm 0.84^{\mathrm{a}}$ & $17.83 \pm 1.0^{\mathrm{ab}}$ & $17.5 \pm 1.0^{\mathrm{a}}$ & $19.16 \pm 0.5^{\mathrm{a}}$ & $18.00 \pm 1.0^{\mathrm{ab}}$ & $91.65 \pm 1.0^{\mathrm{a}}$ & V.good \\
\hline 5 & $18.16 \pm 0.5^{\mathrm{a}}$ & $19.0 \pm 0.5^{\mathrm{a}}$ & $18.50 \pm 0.5^{\mathrm{a}}$ & $17.16 \pm 0.1^{\mathrm{b}}$ & $18.33 \pm 0.3^{\mathrm{ab}}$ & $91.15 \pm 1.0^{\mathrm{a}}$ & V.G \\
\hline 6 & $17.50 \pm 1.0^{\mathrm{ab}}$ & $18.26 \pm 0.2^{\mathrm{a}}$ & $17.70 \pm 0.7^{\mathrm{a}}$ & $15.66 \pm 0.2^{\mathrm{d}}$ & $19.16 \pm 0.5^{\mathrm{a}}$ & $88.28^{\mathrm{b}}$ & G. \\
\hline 7 & $17.83 \pm 1.0^{\mathrm{a}}$ & $18.50 \pm 0.5^{\mathrm{a}}$ & $18.16 \pm 0.45$ & $17.16 \pm 0.1^{\mathrm{b}}$ & $19.50 \pm 0.5^{\mathrm{a}}$ & $91.15 \pm 1.0^{\mathrm{a}}$ & V.G \\
\hline 8 & $18.33 \pm 1.0^{\mathrm{a}}$ & $19.0 \pm 1.0^{\mathrm{a}}$ & $18.36 \pm 0.3^{\mathrm{a}}$ & $16.50 \pm 0.5^{\mathrm{c}}$ & $19.06 \pm 0.5^{\mathrm{a}}$ & $91.25 \pm 0.5^{\mathrm{a}}$ & V.G \\
\hline LSD 5\% & 1.42 & 1.14 & 1.02 & 0.54 & 0.97 & 1.48 & - \\
\hline
\end{tabular}

Values are means of ten replicates \pm SD

The mean values with different letter or letters within the same column indicates significant differences $(\mathrm{p} \leq 0.05)$

90-100 very good(VG), 80-90 Good(G), 70-79 Satisfactory(S), Less than 70 Questionable (Q).

Physical properties of wheat flour crackers: Table (12) show that moisture content of supplemented crackers samples (as indicated by crispy) ranged from 5.3\% to $5.8 \%$ which increased about $8.6 \%$ to $19.5 \%$ as that of control (4.6\%), this may be due to the difference in water holding capacity of raw materials of the formula of these samples. Gandhi and Srivastava (2007) who reported that water holding capacity 
and oil holding capacity were high for sesame processing waste. The increment in moisture caused increment in weight of supplemented samples. There was decrement observed for height, volume and specific volume comparing with control, this may be due to increase in fiber content of supplemented crackers.

Table 12. physical properties of crackers samples

\begin{tabular}{|l|l|l|l|l|l|}
\hline Sample & Moisture \% & Weight $(\mathrm{gm})$ & $\begin{array}{l}\text { Height } \\
(\mathrm{mm})\end{array}$ & $\begin{array}{l}\text { Volume } \\
\left(\mathrm{cm}^{3}\right)\end{array}$ & $\begin{array}{l}\text { Specific } \\
\text { Volume } \\
\left(\mathrm{cm}^{3} / \mathrm{gm}\right)\end{array}$ \\
\hline $\begin{array}{l}\text { Control } \\
\text { wheat } \\
\text { crackers }\end{array}$ & $4.60 \pm 0.4^{\mathrm{ab}}$ & $5.00 \pm 0.5^{\mathrm{ab}}$ & $12.0 \pm 0.2^{\mathrm{a}}$ & $6.80 \pm 0.2^{\mathrm{a}}$ & $1.36 \pm 0.2^{\mathrm{a}}$ \\
\hline 1 & $5.00 \pm 0.2 \mathrm{a}$ & $5.30 \pm 0.2^{\mathrm{ab}}$ & $11.40 \pm 0.2^{\mathrm{b}}$ & $6.40 \pm 0.2^{\mathrm{a}}$ & $1.21 \pm 0.2^{\mathrm{a}}$ \\
\hline 2 & $5.50 \pm 0.2^{\mathrm{a}}$ & $5.80 \pm 0.2^{\mathrm{a}}$ & $11.00 \pm 0.1^{\mathrm{c}}$ & $6.00 \pm 0.2^{\mathrm{a}}$ & $1.03 \pm 0.2^{\mathrm{a}}$ \\
\hline 3 & $5.20 \pm 0.5^{\mathrm{a}}$ & $5.40 \pm 0.2^{\mathrm{a}}$ & $11.00 \pm 0.1^{\mathrm{c}}$ & $6.30 \pm 1.0^{\mathrm{a}}$ & $1.17 \pm 1.0^{\mathrm{a}}$ \\
\hline 4 & $5.30 \pm 0.3 \mathrm{a}$ & $5.70 \pm 0.2^{\mathrm{a}}$ & $10.30 \pm 0.3^{\mathrm{d}}$ & $6.00 \pm 0.5^{\mathrm{a}}$ & $1.05 \pm 1.0^{\mathrm{a}}$ \\
\hline LSD 5\% & 0.55 & 0.46 & 0.31 & 0.84 & 1.04 \\
\hline
\end{tabular}

Values are means of three replicates \pm SD

The mean values with different letter or letters within the same column indicates significant differences $(p \leq 0.05)$

Physical properties of free gluten crackers: Table (13) shows that all samples of crackers which containing sesame processing wastes had higher moisture content. It ' s ranged from $5.5-7 \%$ compared to the control $(5 \%)$, such increase in moisture may be due to the levels of substituted fiber which absorbed more water than starch Doweidar and Kamel (2011). Also the results show that height, volume and specific volume in all samples of crackers decreased by increasing corn flour substituted from 15 and $20 \%$ for sesame processing wastes, this could be due to increase in fiber content and the absence of gluten. The weights of crackers were increased by increasing corn flour substitution from 15 to $20 \%$ as a result of moisture increasing.

Table 13. physical properties of free gluten crackers

\begin{tabular}{|l|l|l|l|l|l|}
\hline Sample & Moisture \% & $\begin{array}{l}\text { Weight } \\
(\mathrm{g})\end{array}$ & Height $(\mathrm{mm})$ & $\begin{array}{l}\text { Volume } \\
\left(\mathrm{cm}^{3}\right)\end{array}$ & $\begin{array}{l}\text { Specific } \\
\text { Volume } \\
\left(\mathrm{Cm}^{3} / \mathrm{g}\right)\end{array}$ \\
\hline $\begin{array}{l}\text { Control corn } \\
\text { crackers }\end{array}$ & $5.00 \pm 0.5^{\mathrm{abc}}$ & $4.50 \pm 0.5^{\mathrm{ab}}$ & $10.0 \pm 0.5^{\mathrm{a}}$ & $6.0 \pm 05^{\mathrm{a}}$ & $1.33 \pm 0.5^{\mathrm{a}}$ \\
\hline 5 & $5.50 \pm 0.5^{\mathrm{ab}}$ & $4.60 \pm 0.4^{\mathrm{ab}}$ & $9.50 \pm 0.5^{\mathrm{a}}$ & $5.50 \pm 0.5^{\mathrm{ab}}$ & $1.22 \pm 0.5^{\mathrm{a}}$ \\
\hline 6 & $6.00 \pm 0.5^{\mathrm{ab}}$ & $4.80 \pm 0.20^{\mathrm{ab}}$ & $9.40 \pm 0.4^{\mathrm{a}}$ & $5.0 \pm 0.5^{\mathrm{ab}}$ & $1.04 \pm 0.4^{\mathrm{a}}$ \\
\hline 7 & $6.26 \pm 0.3^{\mathrm{a}}$ & $5.00 \pm 0.2^{\mathrm{a}}$ & $7.40 \pm 4.0^{\mathrm{b}}$ & $4.50 \pm 0.50^{\mathrm{ab}}$ & $0.90 \pm 0.5^{\mathrm{a}}$ \\
\hline 8 & $7.00 \pm 0.5^{\mathrm{a}}$ & $5.5 \pm 0.5^{\mathrm{a}}$ & $7.10 \pm 0.5^{\mathrm{b}}$ & $4.0 \pm 0.50^{\mathrm{abc}}$ & $0.73 \pm 0.51^{\mathrm{a}}$ \\
\hline LSD 5 \% & 0.75 & 0.62 & 1.82 & 0.73 & 0.77 \\
\hline
\end{tabular}

Values are means of three replicates \pm SD

The mean values with different letter or letters within the same column indicates significant differences $(p \leq 0.05)$

Evaluation of the efficiency and activity of the antioxidant compounds of

wheat crackers: Antioxidants are compounds that can delay or inhibit the oxidation 
of lipid and high fat foods or other molecules by inhibiting the initiation or propagation of oxidizing chain reaction Hollman and Katan 1999 ).

Nowadays, various natural antioxidant are used for preservation or retardation of lipid peroxidation, there are many natural occurring compounds that have antioxidant properties. Among these are tocopherols, ascorbic acid, polyphenols, flavonoids, tannins and saponins (Hollman and Katan 1999).

From the results presented in Table (14), it could be noticed that the peroxide value of crackers increased with increasing storage period. The crackers supplemented with DSC and SSWPT at different levels showed low peroxide value compared to the control, which its fat contents ranged from $11.0-11.61 \%$, after storage at room temperature. The peroxide value of wheat crackers and sesame by products crackers ranged from 0.92 to 5.1 milli equivalents of peroxide $/ \mathrm{kg}$ fats all over storage period conceded accepted Allen and Hamilton (1983).

Table 14. peroxide value of crackers samples during storage (milli equivalents of peroxide/kg oile).

\begin{tabular}{|l|l|l|l|}
\hline Sample & Zero time & 2 weeks & 4 weeks \\
\hline Control wheat crackers & $0.92 \pm 0.01^{\mathrm{b}}$ & $2.50 \pm 0.2^{\mathrm{a}}$ & $5.10 \pm 1.0^{\mathrm{a}}$ \\
\hline 1 & $1.54 \pm 0.1^{\mathrm{a}}$ & $1.8 \pm 0.2^{\mathrm{b}}$ & $3.10 \pm 0.1^{\mathrm{a}}$ \\
\hline 2 & $0.96 \pm 0.02^{\mathrm{b}}$ & $1.40 \pm 0.1^{\mathrm{c}}$ & $2.80 \pm 0.2^{\mathrm{b}}$ \\
\hline 3 & $0.90 \pm 0.1^{\mathrm{b}}$ & $1.10 \pm 0.1^{\mathrm{cd}}$ & $2.70 \pm 0.5^{\mathrm{b}}$ \\
\hline 4 & $0.89 \pm 0.1^{\mathrm{b}}$ & $0.93 \pm 0.01^{\mathrm{cd}}$ & $2.10 \pm 0.3^{\mathrm{bc}}$ \\
\hline Control with BHA500ppm & $0.92 \pm 0.02^{\mathrm{b}}$ & $1.30 \pm 0.1^{\mathrm{c}}$ & $1.40 \pm 0.2^{\mathrm{bc}}$ \\
\hline LSD 5\% & 0.11 & 0.24 & 0.78 \\
\hline
\end{tabular}

BHA:butylated hydroxyl anisole

Values are means of three replicates \pm SD

The mean values with different letter or letters within the same column indicates significant differences $(p \leq 0.05)$

Evaluation of the efficiency and activity of the antioxidant compounds of corn flour crackers: Table (15) illustrates the effect of various supplementation and storage period on peroxide value of blended crackers. It could be noticed that the peroxide value for crackers supplemented with different levels of DSC and SSWPT decreased compared to the control during storage. Among all samples, the crackers supplemented with SSWPT showed the lowest PV throughout storage period than the others, followed by crackers supplemented with DSC. These results suggested that sesame processing wastes were effective in suppressing the oxidation of crackers. The anti-oxidative effect may have contributed to the oxidative stability of crackers with addition of natural antioxidants. 
Table 15. peroxide value of free gluten crackers samples during storage (milli equivalents of peroxide/ $\mathrm{kg}$ oile).

\begin{tabular}{|l|l|l|l|}
\hline Sample & Zero time & 2 weeks & 4 weeks \\
\hline Control corn crackers & $1.80 \pm 0.2^{\mathrm{a}}$ & $4.5 \pm 0.1^{\mathrm{a}}$ & $6.40 \pm 1.0^{\mathrm{a}}$ \\
\hline 5 & $1.70 \pm 0.4^{\mathrm{a}}$ & $3.5 \pm 0.33^{\mathrm{b}}$ & $3.50 \pm 0.5^{\mathrm{b}}$ \\
\hline 6 & $1.60 \pm 0.5^{\mathrm{a}}$ & $2.3 \pm 0.1^{\mathrm{c}}$ & $2.4 \pm 0.2^{\mathrm{b}}$ \\
\hline 7 & $1.50 \pm 0.5^{\mathrm{a}}$ & $2.5 \pm 0.2^{\mathrm{c}}$ & $3.0 \pm 0.1^{\mathrm{bc}}$ \\
\hline 8 & $1.40 \pm 0.3^{\mathrm{a}}$ & $2.2 \pm 0.2^{\mathrm{c}}$ & $2.2 \pm 0.2^{\mathrm{bc}}$ \\
\hline Control withBHA500ppm & $0.93 \pm 0.03^{\mathrm{b}}$ & $1.3 \pm 0.2^{\mathrm{d}}$ & $1.90 \pm 0.1^{\mathrm{bc}}$ \\
\hline LSD 5\% & 0.58 & 0.33 & 0.76 \\
\hline
\end{tabular}

BHA:butylated hydroxyl anisole. Values are means of three replicates \pm SD

The mean values with different letter or letters within the same column indicates significant differences $(p \leq 0.05)$

\section{CONCLUSION}

From this study it could be concluded that sesame processing wastes such as defatted sesame cake (from oil processing) and sesame sieved waste from tahini processing are considered as good sources for protein, minerals, crude fiber and antioxidants to produce supplemented healthy wheat flour crackers and corn flour crackers free gluten for celiac diseases these products could be preferable and acceptable.

\section{REFERENCES}

1. AACC. 2002. Approved Method of American Association of Cereal Chemists Approved Methods the AACCpublished by the American Association of Cereal Chemists. $13^{\text {th }}$ Ed., Inc. St. Paul, Minnesota, USA.

2. Abd El-Monem, A. S. 2006. Chemical, technological and biological studies on sesame seed processing wastes for producing some functional foods. PhD. Fac. Home Economics, Dept. Nutrition and Food Sci., Minufiya Univ.

3. Ajayi, I. A, Adeshina, A. I. 2014. Chemical Analysis and Toxicological Assessment of Sesamum indicum Seed Cake on Albino Rats. J. of Environmental science, Technology and Food Technology, 8 (7): 60-66.

4. Allen, J. C. and Hamilton, R. J. 1983. Rancidity in Food pp.85 and 173. Applied Science Publishers, New York.

5. AOAC (Association of Official Analytical Chemists). 2005. Official Methods Of Analysis.; 17 Th Ed. Washington, D.C., USA.

6. Bates, R., Gvaham, H.,Mattews, R. and Close, L. 1991. Bread fruit chips preparation, stability and acceptability. J. Food Sci., 56 (6): 1608-1618.

7. Doweidar, M. M. and Kamel, A. S. 2011. Using of quinoa for production of some bakery products (gluten-free). Egyptian J. of Nutrition,xxvi (2):21-51.

8. Elleuch, M., Bedigian,D., Besbes, S. ,Christophe Blecker,C. and Hamadi Attia,H. 2012. Dietry fiber characteristics and antioxidant activity of sesame seed coats (testae).International J.Food Properties, 15:25-37 
9. FAO/WHO 1991. Protein Quality Evaluation. Reports of a join FAO/WHO expert Consultion, Food and Agriculture Organization of the United Nations, FAO, Rome. Pp 1-66.

10. Fraser, J.R. and Holmes, D. C. 1959. Proximate analysis of wheat flour carbohydrate. In. Analysis of whole meal flour and its some of its fractions. J. of Science of Food and Agricultural, 10 (9): 506-512.

11. Gandhi, A.P. and Srivastava, J. 2007. Studies on the production of protein isolates from defatted sesame seed (Sesamum indicum flour and their nutritional profile. ASEAN Food Journal, 14 (3), 175-180.

12. Gao,X., Ohlander, M., Jeppsson, N., Bjork, L. and Trajkovski. V. 2000. Changes in antioxidant effects and their relationship to phytonutrients in fruits of sea buckthorn (Hippophae rhamnoides L.). during maturation. J. Agric. Food Chem., 48: $1485-1490$.

13. Grigelmo-Miguel, N.; Martin-Belleso, O. 1999. Comparison of dietary fibre from byproducts of processing fruits and green from cereals. LWT-Food Science and Technology,32: 503-508.

14. -Hassan, M. A. 2013. Studies on Egyptian Sesame Seeds (Sesamum indicum L.) and its products. 3.Effect of Roasting Process on Gross Chemical Composition,Functional Properties, Antioxidative Components and Some Minerals of Defatted Sesame Seeds Meal (Sesamum indicum L.). World Journal of Dairy \& Food Sciences 8 (1): 51-57.

15. Hollman, P.C.H. and Katan, M.B. 1999. Dietary flavonoids: Intake, health effects and bioavailability. Food Chem. Toxicol. 37, 937-942.

16. Prakritiz, J.,P.,Kumar, B. and Tanwar, B. 2016. Celiac disease: Overview and considerations for development of gluten-free foods. Food Science and Human Wellness, 5(4): 169-176.

17. Siddhuraju, A., Hohan, B. and Beckera, K.S. 2000. Studies on the antioxidant activity of Indian Laburnum (Cassia fistulaL.): A preliminary assessment of crude extracts from stem bark, leaves, flowers and fruit pulp. Food Chemistry,79: 61-67.

18. Snedecor, G. W. and Cochran, W. G. 1980. Statistical methods $7^{\text {th }}$ ed. Iowa State Univ., Press. Ames., Iowa, USA.

19. Suja, K. P., John, T., AbrahamSelvam N., Thamizh, A. and Jayalekshmy, C. 2004. Antioxidant efficacy of sesame cake extract in vegetable oil protection. Food Chemistry,84 (3): 393-400.

20. -Wade, P. 1988. Recipe of biscuits in investigation. Applied Science, 1: 102104.LTD, London, U.K. 


\section{الإستفادة من مخلفات تصنيع السمسم \\ فى تحضير بعض المخبوزات الوظيفية}

\section{هدى حسن أبو السعود حافظ}

$$
\text { معهد بحوث تكنولوجيا الأغذيه - مركز البحوث الزراعيه-جيزة - مصر • }
$$

تهدف هذه الدراسة إلي الإستفادة من كسب زيت السمسم و من مخلف نخل السمسم من

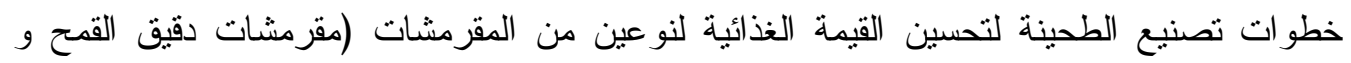

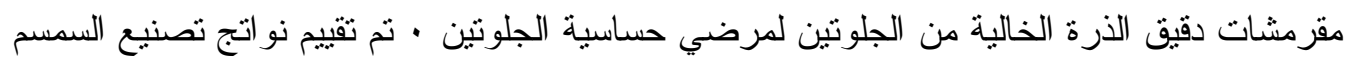

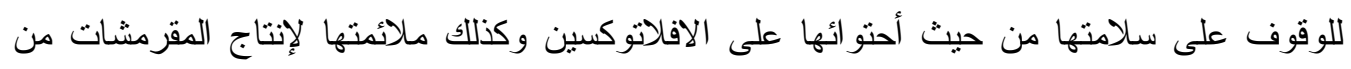

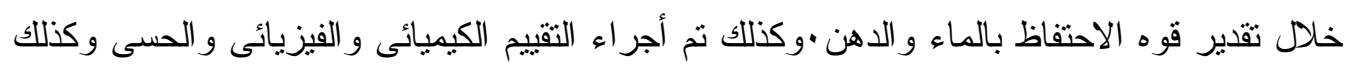

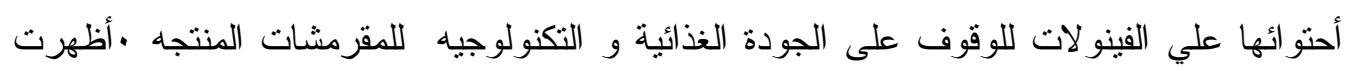
النتائج خلو منتجات تصنيع السمسم من الافلاتوكسين وكذللك ثبت جودتها من حيث الاحتفاظ بالماء

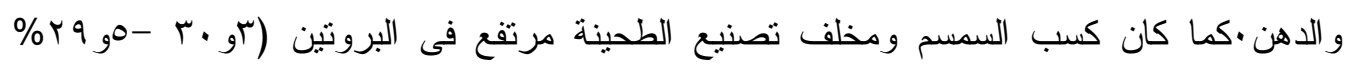

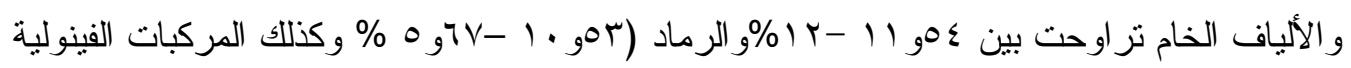

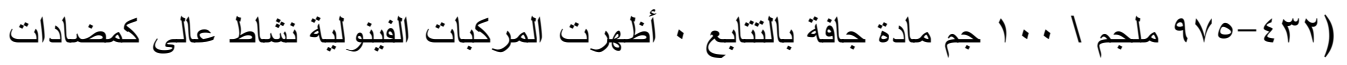

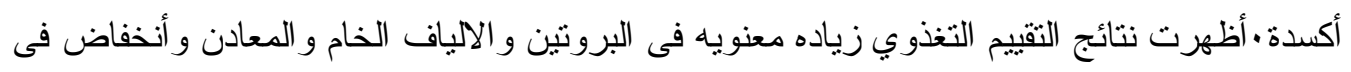

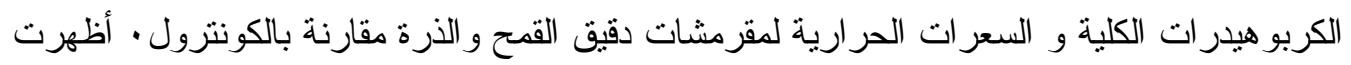
نتائج التقيم الحسي للمنتجات وجود قبول عالى لدي المحكمين وبدون فروق معنويه مع الكونترول .

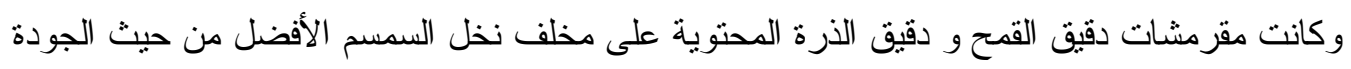

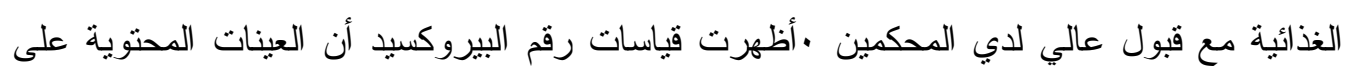

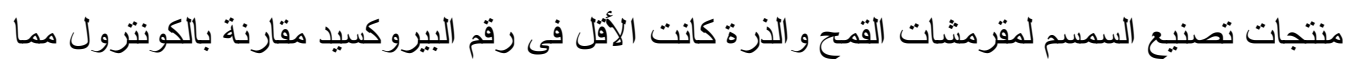

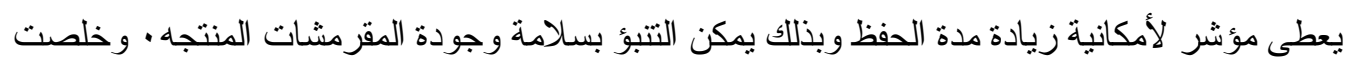

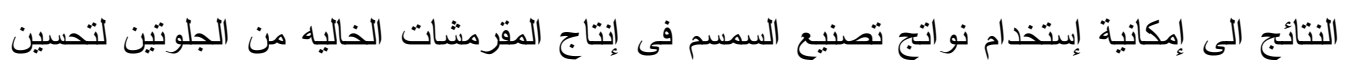

